\title{
Meritocracy in Singaporean Educational System: Inequality in Admission to Secondary Schools
}

\author{
Fangyao Zhang \\ Department of Education, The University of Melbourne, VIC 3010, Australia \\ Email: fangyao.zhang@student.unimelb.edu.au
}

\begin{abstract}
This paper explores the fairness of meritocracy concerning admission to secondary schools based on the Primary School Leaving Examination (PSLE) in Singapore. The Ministry of Education has consistently adopted the ideology of meritocracy as so to select talented students, stimulate effort, and optimize the allocation of rewards. The PSLE results can largely determine students' educational tracks and even career orientation in Singapore. The paper shows how the principle of meritocracy works and how the government uses meritocratic belief in the education system. The paper argues that meritocracy has posed a threat to equality in admission to secondary schools in Singapore. The findings indicate that the meritocratic policy does not recognize both the importance of family SES and the gap between elite schools and neighbourhood schools in the Singapore education system. Students with wealthy and well-educated parents and students in elite schools are more likely to acquire better educational attainment, since they tend to gain more cultural capital from family and social capital from school. The principle of meritocracy fails to allocate opportunities fairly to students and can lead to inequality in education and exacerbate educational stratification.
\end{abstract}

Keywords: meritocracy, admission to secondary schools, social capital, cultural capital, inequality

\section{Introduction}

The principle of meritocracy is prominent in establishing the structure of high-stakes national examinations. It can influence schools' distribution of resources, largely determining which secondary school and stream pupils are allocated and assigning different citizenship roles to young adolescents. Politicians insist that meritocracy is a fair system that can give students equal opportunities in education and assign them to schools according to their talent plus effort (Elford, 2016)such that social class represents an objectionable determinant of unequal educational prospects even when its influence is mediated through the cultivation of talent and effort. This argument is further supported through an explanation that the character of social class as a systemic social source of the structure of individuals' opportunities makes it an objectionable influence on educational opportunities.","container-title":"Res Publica","DOI":"10.1007/s11158-015-9280-3","ISSN":"1356-4765, 1572-8692","issue":"3","journalAbbreviation":"Res Publica ","language":"en","page":"267-284","source":"DOI.org (Crossref. However, this paper will articulate that meritocracy is not fair in terms of admission to secondary schools.

\section{Context}

Meritocracy plays an important role in Singapore governance and education system. Politicians have adopted the principle of meritocracy to select talented candidates, optimise the allocation of rewards, and legitimate differences.

Singaporean pupils need to attend the national Primary School Leaving Examination (PSLE) at the end of the sixth year of primary school, which tests students' competency in mathematics and science, their English proficiency, and their respective mother tongue languages (Tamil, Malay, or Chinese) (Koh, 2014). The examination results determine students' enrolment in selective secondary schools and place them into a particular education track that can profoundly affect their career orientation. Students with high examination results in the PSLE are eligible for the Integrated Programme (IP), a six-year programme held by elite secondary schools in Singapore (Ministry of Education, 2019). The academically strong students are exposed to various courses and subjects, including scientific research and philosophy.

The majority of students of each cohort are placed in the four-year Express course leading to the General Certificate of Education Ordinary Level examinations (Ho, 2020)geography and history teachers make meaning of the concept of meritocracy and its role in the education system. The findings indicate the partici pants simultaneously adopted and challenged the meritocratic values and beliefs promoted by the Singapore state. The teachers strongly believed that the principle of meritocracy helped promote educational and social equality, but they were also deeply con cerned about the limitations of meritocracy and the impact of structural and institutional inequalities on educational equality. Even though most participants 
were able to identify and critique structural inequities and explain how this could affect students' academic achievement, their awareness of the limitations of the meritocratic system did not undermine their belief in the system of meritocracy and they could not envisage alternative systems for determining educational access and equality.","container-title":"Cambridge Journal of Education","DOI":"10.1080/0305764X.2020.1796927","ISSN":"0305-764X, 1469-3577","journalAbbreviation ":"Cambridge Journal of Education","language":"en","page":"1-21","source":"DOI.org (Crossref. The least academically able students attend the Normal Technical course and have fewer academic subjects and more limited academic resources since they are labelled as "low progress"(Lim \& Tan, 2020).

\section{Argument}

The primary school leaving examination (PSLE) greatly determines students' academic and career development. Although politicians in Singapore claim that the meritocracy can provide fair opportunities and select high ability students efficiently, this paper argues that admission to secondary schools based on PSLE results in Singapore is unfair.

First, the meritocracy in this context ignores students' family socioeconomic background. According to Bourdieu (1973), the possession of cultural capital is closely associated with social class, which can be inculcated in the higherclass family and support high-class individuals to succeed in the education system. Students with higher SES backgrounds possess more parental cultural capital, acquire the class advantage from their higher-class families, and attain high levels and quality of education (Mijs, 2016; Sullivan, 2021)psychology and economics that has extensively documented the unfulfilled promise of meritocracy in education. I argue that the lesson learned from this literature is threefold: (1.

Family background is strongly linked with children's educational attainment and transitions. There is a correlation between parental and children's academic performance. Children of well-educated parents tend to attend quality schools and attain academic success than children of low-educated parents in the meritocratic education system (Mijs, 2016)psychology and economics that has extensively documented the unfulfilled promise of meritocracy in education. I argue that the lesson learned from this literature is threefold: (1. Well-educated parents attach great importance to pupils' upbringing and provide them with a cognitively stimulating environment through transmitting their knowledge and offering intellectual resources (Sullivan, 2021).

Additionally, parents with high income tend to invest more in children's education1990. To ensure children succeed in this national examination, roughly $80 \%$ of Singaporean parents spend money on children's academic classes and private tutoring (Tan, 2017)1990. Parents with higher incomes tend to invest more in children's educational enrichment classes, providing children with various resources and chances to acquire disciplinary knowledge and high academic results 1990.

Moreover, meritocracy disregards the disparities between elite schools and neighbourhood schools. Students in elite schools have access to more educational resources in Singapore, including competent teachers, adequate facilities, and quality programs (Mathews \& Lim, 2017). Also, students in elite schools tend to benefit students from excellent studentteacher ratios and small class sizeswe use the theoretical framework of structurereinforced privilege to highlight how parental advantage can be compounded by complex choice structures, both the number of choices and the complicated selection criteria. We focus on a case study of Singapore's primary school registration process which has not been previously examined in the academic literature. Using a discourse analysis of newspaper coverage and a Singaporean website for parents, we demonstrate that the primary enrollment system creates confusion among parents, and ultimately allows privileged parents to gain an admissions advantage in perceived elite schools. Numerous admission preferences, while initially intended to strengthen family-school ties, rewards those with resources, furthering the perception and reality of economic inequality. We close with recommendations to simplify school choice systems giving priority to families with limited resources.","genre":" preprint","language":"en","note":"DOI: 10.35542/osf.io/sc6m9","publisher":"EdArXiv","source":"DOI.org (Crossref. This quality learning environment can build positive student-teacher relationships through increasing in-class interactions and collaboration, which allow students to acquire a deep understanding of knowledge and have the motivation to learn (Koh, 2014).

Also, social capital in elite schools can motivate students to acquire higher achievement through teaching cultural norms and values (Dufur et al., 2013)we show that capital from each context is helpful, with social capital in the family more influential than social capital at school. We discuss the implications of these findings for research on child achievement and for studies of inequality generally.","container-title":"Research in Social Stratification and Mobility","DOI":"10.1016/j.rssm .2012.08.002","ISSN":"02765624","journalAbbreviation":"Research in Social Stratification and Mobility","language":"en" ,"page":"1-21","source":"DOI.org (Crossref. Elite schools can identify and cultivate students' talents and make merit. Elite schools teach students to act meritoriously and expect academic achievement to make them into elites through consistent interactions at school (Mijs, 2016). 
The disparities between elite schools and neighbourhood schools may lead to inequality in education and exacerbate the educational stratification (Koh, 2014). Although educationists claimed the importance for students to attend schools that are suitable for them rather than choosing a brand name school, it is still widely believed that it mattered studying in an elite school because of its privileges.

\section{Conclusion}

To sum up, the meritocracy is not fair concerning admission to secondary schools based on PSLE results in Singapore. Meritocracy does not recognise how family SES influences students' academic performance and the gap between neighbourhood schools and elite schools, which can profoundly affect pupils' academic performance and enrolment in secondary schools. The meritocracy in the Singapore education system can lead to inequality and exacerbate educational stratification.

\section{References}

[1] Bourdieu, P. (1973). Cultural reproduction and social reproduction. London: Tavistock, 178, 71-112.

[2] Debs, M., \& Cheung, H. S. (2020). Structure-reinforced privilege: Educational inequality in the Singaporean primary school choice system [Preprint]. EdArXiv.

[3] Dufur, M. J., Parcel, T. L., \& Troutman, K. P. (2013). Does capital at home matter more than capital at school? Social capital effects on academic achievement. Research in Social Stratification and Mobility, 31, 1-21.

[4] Elford, G. (2016). Social class, merit and equality of opportunity in education. Res Publica, 22(3), $267-284$.

[5] Ho, L.-C. (2012). Sorting citizens: Differentiated citizenship education in Singapore. Journal of Curriculum Studies, 44(3), 403-428.

[6] Ho, L.-C. (2020). 'Our students do not get that equal chance': Teachers' perspectives of meritocracy. Cambridge Journal of Education, 1-2.

[7] Koh, A. (2014). Doing class analysis in Singapore's elite education: Unravelling the smokescreen of 'meritocratic talk.' Globalisation, Societies and Education, 12(2), 196-210.

[8] Lim, L., \& Tan, M. (2020). Meritocracy, policy and pedagogy: Culture and the politics of recognition and redistribution in Singapore. Critical Studies in Education, 61(3), 279-295.

[9] Mathews, M., Lim, L., \& Teng, S. (2017). Parents' perceptions of the Singapore primary school system. $27,55$.

[10] Ministry of Education. (2021, March 04). Education Statistics Digest 2020. Available from: https://www.moe.moe.gov. sg/about-us/publications/education-statistics-digest.

[11] Mijs, J. J. B. (2016). The unfulfillable promise of meritocracy: Three lessons and their implications for justice in education. Social Justice Research, 29(1), 14-34.

[12] Sullivan, A. (2021). Cultural capital and educational attainment. Sociology, 35(4), 893-912.

[13] Tan, C. (2017). Private supplementary tutoring and parentocracy in Singapore. Interchange, 48(4), 315-329. 